\title{
An 11-year-old boy with immediate allergic reaction to articaine but not to lidocaine
}

\author{
Wasu Kamchaisatian ${ }^{1 *}$, Nopalit Insorn², Nattipat Juthacharoenwong ${ }^{2}$, Surangkana Techapaitoon ${ }^{2}$ \\ From 6th Drug Hypersensitivity Meeting (DHM 6) \\ Bern, Switzerland. 9-12 April 2014
}

\section{Background}

Adverse reaction to local anesthetic agents is relatively common, but true IgE-mediated hypersensitivity is rare. Allergic reaction to these drugs can be harmful especially in the circumstance with non-allergy physician i.e. dentist performing dental procedure which may cause severe systemic reaction.

\section{Objective}

To report a boy with immediate local reaction to articaine, a local anesthetics widely used in dental procedure, with demonstrable IgE antibody to articaine, but not to lidocaine.

\section{Case report}

An 11 years old boy had history of lip swelling and itching after dental procedure with injection of local anesthetic drug, Articaine (Ubistesin ${ }^{\circledR}$ ). There was no any skin rash or hives on any parts of the body and no other systemic symptoms. Lip swelling lasted for 2 hours and then spontaneously resolved. The patient was consulted for suspicious allergy to articaine. After thoroughly history taking, he also has allergic rhinitis and previous history of asthma, but no any allergy to latex or drugs including sulfonamide. Skin prick test and intradermal test were done with undiluted and 1/10 dilution of the following amide local anesthetics in a single-use dental cartridge of: articaine, lidocaine, mepivacaine and levobupivacaine; but not to procaine, the ester local anesthetics, since it was unavailable. The results revealed markedly positive to intradermally testing of undiluted and 1/10 dilution of articaine and mepivacaine, but negative to lidocaine and levobupivacaine. We did not perform provocative dose challenge

'Samitivej International Children's Hospital, Bangkok Hospital Group, Allergy and Immunology Center, Thailand

Full list of author information is available at the end of the article to lidocaine or levobupivacaine, however, subsequently; the patient was undergone dental procedure using lidocaine as the local anesthetics with no any local or systemic reaction.

\section{Conclusion}

When allergic reaction to local anesthetics is suspected, an allergy consultation for skin testing and provocative dose challenge should be appreciated. This may help confirming the suspected culprit agent that may be safely used, or moreover, to identify a suitable alternative.

\section{Authors' details \\ 'Samitivej International Children's Hospital, Bangkok Hospital Group, Allergy and Immunology Center, Thailand. 'Samitivej International Children's \\ Hospital, Bangkok Hospital Group, Pediatric Center, Thailand.}

Published: 18 July 2014

doi:10.1186/2045-7022-4-S3-P71

Cite this article as: Kamchaisatian et al: An 11-year-old boy with

immediate allergic reaction to articaine but not to lidocaine. Clinical and Translational Allergy 2014 4(Suppl 3):P71.

Submit your next manuscript to BioMed Central and take full advantage of:

- Convenient online submission

- Thorough peer review

- No space constraints or color figure charges

- Immediate publication on acceptance

- Inclusion in PubMed, CAS, Scopus and Google Scholar

- Research which is freely available for redistribution

Submit your manuscript at www.biomedcentral.com/submit
() Biomed Central 